\title{
CONTINUOUS VERTICAL CASTING OF A NiTi ALLOY
}

\section{VERTIKALNO KONTINUIRNO LITJE NiTi ZLITINE}

\author{
Aleš Stambolić' ${ }^{1,2}$, Ivan Anžel ${ }^{3}$, Gorazd Lojen ${ }^{3}$, Aleksandra Kocijan', \\ Monika Jenko ${ }^{1,2}$, Rebeka Rudolf ${ }^{3,4}$ \\ ${ }^{1}$ Institute of Metals and Technology, Lepi pot 11, 1000 Ljubljana, Slovenia \\ 2Jožef Stefan International Postgraduate School, Jamova 39, 1000 Ljubljana, Slovenia \\ ${ }^{3}$ University of Maribor, Faculty of Mechanical Engineering, Smetanova 17, 2000 Maribor, Slovenia \\ ${ }^{4}$ Zlatarna Celje d.d., Kersnikova 19, 3000 Celje, Slovenia \\ ales.stambolic@imt.si \\ Prejem rokopisa - received: 2016-06-17; sprejem za objavo - accepted for publication: 2016-06-27
}

doi:10.17222/mit.2016.111

\begin{abstract}
In this paper we present research that is connected to the performance of a series of experiments combined with the vacuum-induction melting and continuous vertical casting of a NiTi alloy in order to produce the strand. The theoretical chosen parameters made it possible to obtain a continuously cast strand with a diameter of $11 \mathrm{~mm}$. The strand microstructures were investigated with a light and scanning electron microscope, while the chemical composition of the single phase was identified with the semi-quantitative micro-analysis energy-dispersive X-ray spectroscopy and inductively coupled plasma - optical emission spectrometry. The research showed that the microstructure is dendritic, where in the inter-dendritic region the eutectic is composed of a dark NiTi phase and a bright $\mathrm{TiNi}_{3-x}$ phase. In some areas we found $\mathrm{Ti}$ carbides and phases rich in $\mathrm{Fe}$. The micro-chemical analysis of the NiTi strand showed that the composition changed over the cross and longitudinal sections, which is proof that the as-cast alloys are inhomogeneous. In the final part, the electrochemical behaviours of NiTi strand samples were compared to a commercially available NiTi cast alloy with the same composition.
\end{abstract}

Keywords: NiTi alloy, continuous vertical casting, microstructure, potentiodynamic and impedance test

$\mathrm{V}$ tem prispevku predstavljamo raziskavo, ki je povezana z izvedbo niza preizkusov vakuumskega pretaljevanja in sočasnega kontinuirnega vertikalnega litja NiTi zlitine s ciljem odliti palico. Teoretično izbrani parametri so omogočili, da smo uspeli kontinuirno odliti NiTi palico s premerom $11 \mathrm{~mm}$. Dobljeno mikrostrukturo palice smo raziskali s svetlobnim in vrstičnim elektronskim mikroskopom, kemijsko sestavo posameznih faz pa smo identificirali s semi-kvantitativno mikro-kemično analizo Energijsko disperzijsko spektrometrijo in z optičnim emisijskim spektrometrom z induktivno sklopljeno plazmo. Preiskave so pokazale, da je mikrostruktura dendritska, medtem ko s v meddendritskem prostoru nahaja evtektik, sestavljen iz temne NiTi faze in svetle $\mathrm{TiNi}_{3-x}$ faze. Mestoma smo identificirali tudi Ti karbide in fazo bogato s Fe. Mikro-kemična analiza NiTi palice je odkrila, da se sestava spreminja po prerezu in po dolžini, kar nakazuje, da je zlitina po strjevanju nehomogena. V zaključnem delu smo primerjali elektrokemijsko obnašanje vzorcev NiTi palice s komercialno dostopno valjano NiTi zlitino enake sestave.

Ključne besede: NiTi zlitina, vertikalno kontinuirno litje, mikrostruktura, potenciodinamični in impedančni test

\section{INTRODUCTION}

$\mathrm{NiTi}$ alloys are an attractive group that also include nitinol. Nitinol is a group of nearly equiatomic alloys of nickel and titanium which is located in the central region of the NiTi phase diagram and bounded by the $\mathrm{Ti}_{2} \mathrm{Ni}$ and $\mathrm{TiNi}_{3}$ phases. ${ }^{1}$ It exhibits a unique combination of good functional properties and a high mechanical strength, such as super-elasticity and a shape-memory effect, good corrosion resistance, an unusual combination of strength and ductility and excellent biomechanical compatibility. ${ }^{2,3}$ This alloy was developed in the 1970s and its properties have enabled its use especially for biomedical purposes, first in orthodontic treatments, and later on in cardiovascular surgery for stents, guide wires, filters, etc., in orthopaedic surgery for various staples and rods, and in maxillofacial and reconstructive surgery. ${ }^{4}$ In addition to bio-engineering, nitinol has been used in aerospace, automotive, civil and structural engineering. ${ }^{5}$ Super-elastic NiTi is capable of recovering large inelastic strains spontaneously upon unloading. On the other hand, shape memory is exhibited when NiTi recovers large strain deformation upon heating. Both the superelasticity and shape-memory effect are induced in nitinol by reversible, displacive, diffusionless, solid-solid phase transformations from a high-temperature parent phase (austenite) with a highly ordered crystal structure to a low temperature, stress-free martensite that has a less ordered structure. Nitinol is hysteretic, and there are several transformation temperatures, including the austenite start temperature $\left(A_{\mathrm{s}}\right)$, the austenite finish temperature $\left(A_{\mathrm{f}}\right)$ during heating and the martensite start temperature $\left(M_{\mathrm{s}}\right)$ and the martensite finish temperature $\left(M_{\mathrm{f}}\right)$ during cooling. Super-elastic behaviour will only occur if the material is loaded above its $A_{\mathrm{f}}$ temperature. ${ }^{6-8}$

The common production route for a NiTi alloy with a shape-memory effect is known and has been experimented on laboratory equipment with the technological aspects of vacuum induction melting, hot and cold working operations. The process is still being optimized with a particular focus on obtaining a small dimension in the cross-section and with stabilisation of its functional properties over its lifetime. ${ }^{9}$ Vacuum induction melting 
(VIM) is often used as the first technique in the preparation of a melt. Basically, it is a typical melting technique for the production of different NiTi-based alloys. This is appreciated particularly for NiTi alloy due to the strong influence of the chemical composition on the reactivity with oxygen and other elements, leading to oxidation of the NiTi melt. In the second step, such a prepared melt is cast, which enables pouring the molten metal into a mould of the desired shape, and allowing it to solidify. When the molten metal is poured into the mould, chill crystals nucleate on the cold walls of the mould and grow inwards. Conventional casting is a batch process that produces large ingots requiring significant subsequent processing. Large mechanical equipment with high construction and operational costs is necessary to break down most ingots. These problems can be solved by using continuous vertical casting (CVC). ${ }^{10-13}$ With CVC the raw material is placed into a VIM furnace, in which the material melts. After melting, the melt is, based on gravity force, moved against the nozzle, which adjusts the rate and direction of the melt flow. The melt flows through the nozzle into a water-chilled mould, where the melt is solidified, and obtains the final strand shape.

Nitinol is often subjected to deformations or stresses that result in some kinds of mechanical failures. Two very important factors must be considered when using various materials in medicine, i.e., the toxicity of the material and the failure of material. The main problem of NiTi alloys is the high Ni content. Ni releasing can induce toxic, allergic and hypersensitive reactions or tissue necrosis after long-term implantation. To prevent failure and $\mathrm{Ni}$ release, a coating of appropriate thickness must be formed on the NiTi surface. Titanium oxide coatings effectively suppress the nickel ions outleaching. The nitinol surface is spontaneously covered by $\mathrm{Ti}$ dioxide because of the gain in free energy of formation for this

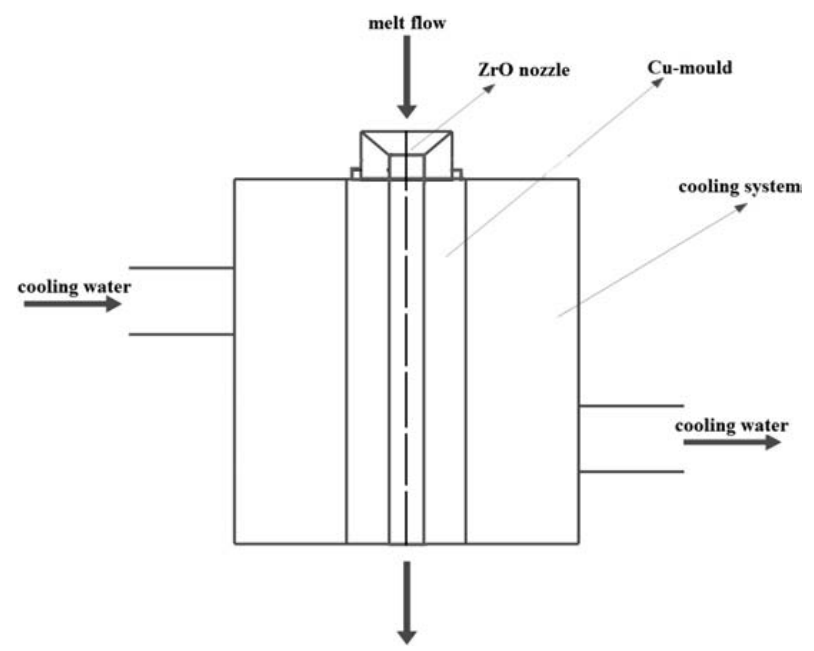

Figure 1: Schematic presentation of copper mould with cooling system at the Faculty of Mechanical Engineering, Maribor, Slovenia Slika 1: Shema bakrene kokile s hladilnim sistemom na Strojni fakulteti v Mariboru, Slovenija oxide compared to the $\mathrm{Ni}$ oxides. However, the oxides formed on the nitinol surface always contain a certain fraction of $\mathrm{Ni}^{14-19}$

The main goal of this work was the performance of the series of experiments combined with vacuum-induction melting and continuous vertical casting of NiTi alloy in order to produce the strand. This was followed by the characterization of the obtained microstructure and finally we compared the electrochemical behaviour between a NiTi strand and commercially available nitinol.

\section{EXPERIMENTAL PART}

\subsection{Continuous vertical casting of NiTi alloy}

The NiTi alloy composed of $50 \%$ of amount fractions of $\mathrm{Ni}$ and $50 \%$ of amount fractions of $\mathrm{Ni}$ was prepared with the combination of techniques: VIM and CVC. A clay-graphite crucible was filled up to $2 / 3$ of its volume due to the high metallostatic pressure (pressure that occurs within a molten metal) with Ti pellets (99.99\% purity) and $\mathrm{Ni}$ tablets (99.99\% purity). By remelting the NiTi alloy with VIM at a temperature of about $1450{ }^{\circ} \mathrm{C}$ a pressure lower than $10^{-2}$ mbar was achieved in the system. The induction power during heating was for first $10 \mathrm{~min} 10 \mathrm{~kW}$, then next $10 \mathrm{~min}$ $20 \mathrm{~kW}$ and in final $5 \mathrm{~min} 30 \mathrm{~kW}$, while during casting it was between 25 and $30 \mathrm{~kW}$. Continuous casting was operating in the mid range frequency $(4 \mathrm{kHz})$. In the experiments a $\mathrm{Cu}$-mould (Figure 1), a $\mathrm{ZrO}_{2}$ nozzle stabilized with $\mathrm{Y}_{2} \mathrm{O}_{3}$ and an $\mathrm{Fe}$ starter bar were applied.

\subsection{Preparing of the samples for further investigation}

The samples for characterization were cut longitudinally (according to the direction of casting) and across the cross-section. For this purpose, an Accutom 50 electronic saw was used for precision cutting. The grinding was performed with 320 grit $\mathrm{SiC}$ abrasive paper, mechanical polishing with MD-Largo discs with 9- $\mu$ m diamond suspension and with peroxide grains in a chemically aggressive suspension - OP-S (colloidal silica). The sample was then etched with Kroll's reagent (3 mL HF, $6 \mathrm{~mL} \mathrm{HNO}_{3}$ and $100 \mathrm{~mL}$ of distilled water).

\subsection{Analytical techniques}

The microstructure was investigated with a light microscope - Microphot FXA, Nikon 3CCD-Hitachi Camcorder HV-C20A and Thermal Field Emission SEM JEOL JSM-6500F equipped with energy-dispersive $\mathrm{X}$-ray spectroscopy (EDS) analytical technique. Chemical analyses were performed by inductively coupled plasma - optical emission spectrometry ICP-OES (Agilent 720).

Potentiodynamic polarisation measurements and electrochemical impedance spectrometry (EIS) have been used to study the electrochemical behaviour of 
samples. All the measurements were recorded by BioLogic Modular Research Grade Potentiostat/Galvanostat/FRA Model SP-300 with an EC-Lab Software and a three-electrode cell. In this cell, the sample was the working electrode, saturated calomel electrode (SCE, $0,242 \mathrm{~V}$ vs. SHE) was used as reference electrode and the counter electrode (CE) was a platinum net. The experiment was held in simulated physiological Hank's solution, containing $8 \mathrm{~g} / \mathrm{L} \mathrm{NaCl}, 0.40 \mathrm{~g} / \mathrm{L} \mathrm{KCl}, 0.35 \mathrm{~g} / \mathrm{L}$ $\mathrm{NaHCO}_{3}, \quad 0.25 \quad \mathrm{~g} / \mathrm{L} \quad \mathrm{NaH}_{2} \mathrm{PO}_{4} \times 2 \mathrm{H}_{2} \mathrm{O}, \quad 0.06 \mathrm{~g} / \mathrm{L}$ $\mathrm{Na}_{2} \mathrm{HPO}_{4} \times 2 \mathrm{H}_{2} \mathrm{O}, \quad 0.19 \mathrm{~g} / \mathrm{L} \quad \mathrm{CaCl}_{2} \times 2 \mathrm{H}_{2} \mathrm{O}, \quad 0.41 \mathrm{~g} / \mathrm{L}$ $\mathrm{MgCl}_{2} \times 6 \mathrm{H}_{2} \mathrm{O}, 0.06 \mathrm{~g} / \mathrm{L} \mathrm{MgSO}_{4} \times 7 \mathrm{H}_{2} \mathrm{O}$ and $1 \mathrm{~g} / \mathrm{L}$ glucose, at $\mathrm{pH}=7.8$ and $37^{\circ} \mathrm{C}$. All the chemicals were from Merck, Darmstadt, Germany. The potentiodynamic curves were recorded after $1 \mathrm{~h}$ of sample stabilisation at the open-circuit potential (OCP), starting the measurement at $250 \mathrm{mV}$ vs. SCE more negative than the OCP. The potential was then increased, using a scan rate of $1 \mathrm{mV} \mathrm{s}^{-1}$, until the transpassive region was reached. Long-term open circuit potentiostatic electrochemical impedance spectra were obtained for the investigated samples. The impedance was measured at the OCP, with sinus amplitude of $5 \mathrm{mV}$ peak to peak and a frequency range of $65 \mathrm{kHz}$ to $1 \mathrm{mHz}$, in the sequence of directly after immersion after 1h, 2 h, 6 h, 12 h, 24 h, 48 h, 72 h, $96 \mathrm{~h}, 120 \mathrm{~h}, 144 \mathrm{~h}, 168 \mathrm{~h}$ and $192 \mathrm{~h}$. The impedance data are presented in terms of Nyquist plots. For the fitting process Zview v3.4d Scribner Associates software was used.

\section{RESULTS AND DISCUSSION}

\subsection{Continuous vertical casting of a NiTi alloy}

The CVC of a NiTi alloy is a complex process that requires precise process parameters. Accurate measurement and regulation of temperature was very difficult because the thermocouple was not in constant contact with the melt due to the potential contamination of the melt and the temperature at the crucible wall is quite different from the actual temperature of the melt. The

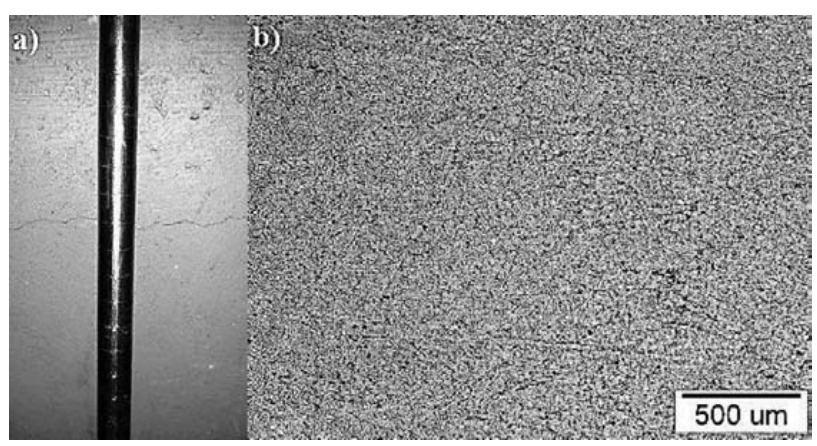

Figure 2: a) NiTi strand, produced at Faculty of Mechanical Engineering, Maribor, Slovenia and b) light microscope image of cross-section of the strand

Slika 2: a) NiTi palica, lita na Strojni fakulteti v Mariboru, Slovenija in b) posnetek prečnega prereza palice, narejen s svetlobnim mikroskopom frequency of induction is also very important for the casting, as a high frequency enables the temperature to rise and low frequency means more intensive stirring. In this case the casting was operated at a mid-range frequency of induction that does not provide adequate mixing power, causing an undesirable chemical composition in some places of the strand. The drawing of the strand was carried out in the sequence of pull - pause, as this reduces the possibility of a reaction between the alloy and the mould, as well as the porosity of the material or the occurrence of cracks in the material. The drawing stroke had a length of between 0 and $10 \mathrm{~mm}$ and the pause lasted between 0 and $1 \mathrm{~s}$. The drawing rate is also an important factor. When the drawing is too slow, the temperature decreases, which leads to solidification of the alloy in the nozzle and retraction of further drawing. This leads to fracture of the strand and the process ends without the desired result. The strand also breaks when the drawing rate is too fast due to the adhesion to the mould and the weakness of the thin solidified skin.

With CVC a strand with diameter of $11 \mathrm{~mm}$ was obtained (Figure 2). ICP analysis for the first attempt of CVC NiTi strand showed a constant material composition of $59.8 \%$ of amount fractions of Ni, $38.9 \%$ of amount fractions of $\mathrm{Ti}$ and $0.3 \%$ of amount fractions of C, EDS analysis showed approximately $1 \%$ of amount fractions of Fe. Deviation from the desired value (50\% of amount fractions of $\mathrm{Ni}$ ) is probably caused by complications with stirring of the melt (better mixing takes place at a lower frequency induction, Ti is very difficult to mix). The source of Fe could be attributed to the Fe screw that was used as a starter bar. During further attempts the chemical composition of the strand varied during casting. At the beginning of drawing XRF analysis showed that the strand was rich in nickel (70.6\% of amount fractions of $\mathrm{Ni} ; 27.1 \%$ of amount fractions of $\mathrm{Ti}$ ) and with the increasing length of the strand the nickel content decreased. Chemical composition during the fracture of the strand was $52 \%$ of amount fractions of $\mathrm{Ni}$ and $47 \%$ of amount fractions of Ti.

\subsection{Microstructure}

\subsubsection{Continuously vertical cast NiTi alloy}

The light microscopy of the strand cross-section reveals the dendritic microstructure (Figure 3), where inside the primary phase NiTi is located. This is according to the Ni-Ti phase diagram where the first solidified phase is NiTi. Dendrites grew in the direction from the coldest location (from the walls of the nozzle) to the middle of the strand. The orientation of dendrites is random. These dendrites are arranged in the matrix of eutectic (composed with $\mathrm{NiTi}$ eut $+\mathrm{TiNi}_{3-\mathrm{x}}$ ). In the microstructure there are no visible defects such as cracks and porosity. 


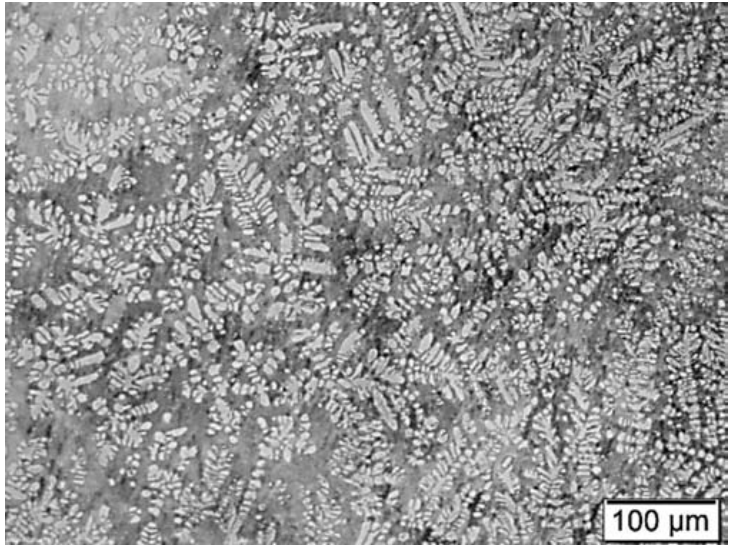

Figure 3: Light microscope image of NiTi strand at 100× magnification

Slika 3: Posnetek NiTi palice na svetlobnem mikroskopu pri 100× povečavi

The NiTi strand contains between $50 \%$ and $60 \%$ of amount fractions of Ni. From the phase diagram (Figure 4) it is clear that this is a hypo-eutectic alloy (according to the eutectic reaction at $1118{ }^{\circ} \mathrm{C}: \mathrm{L} \rightarrow \mathrm{NiTi}+\mathrm{TiNi}_{3}$ ). With an ideal cooling the melt would begin to solidify in the temperature range between $1310{ }^{\circ} \mathrm{C}$ and $1118{ }^{\circ} \mathrm{C}$. From the melt firstly the primary NiTi phase solidifies that would be continuously generated and grew until the eutectic temperature $\left(1118{ }^{\circ} \mathrm{C}\right)$ is reached. At this temperature, the remaining melt solidifies into a eutectic structure composed of a NiTi phase and $\mathrm{TiNi}_{3}$ phase in the form of lamellas.

In the real case, the cooling is non-equilibrium. Solidifying rates are large, but the diffusion rates in the solid state are too small to make it possible to achieve a homogeneous solid phase. A backscattered electrons image (Figure 5) shows a typical dendritic structure (tree-like form) that are solidified primarily (NiTi phase). At the eutectic temperature $\left(1118{ }^{\circ} \mathrm{C}\right)$ solidifies typical

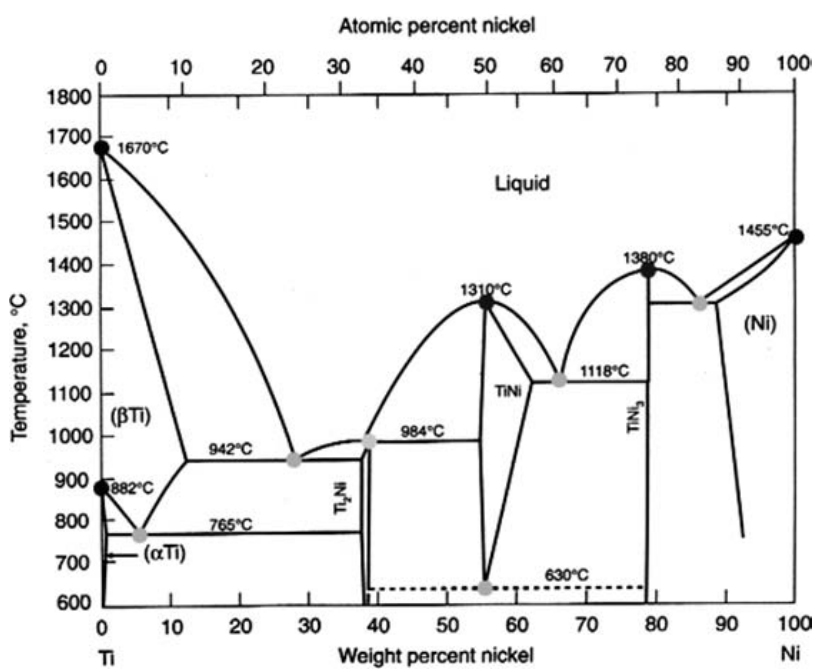

Figure 4: Ni-Ti phase diagram

Slika 4: Fazni diagram Ni-Ti

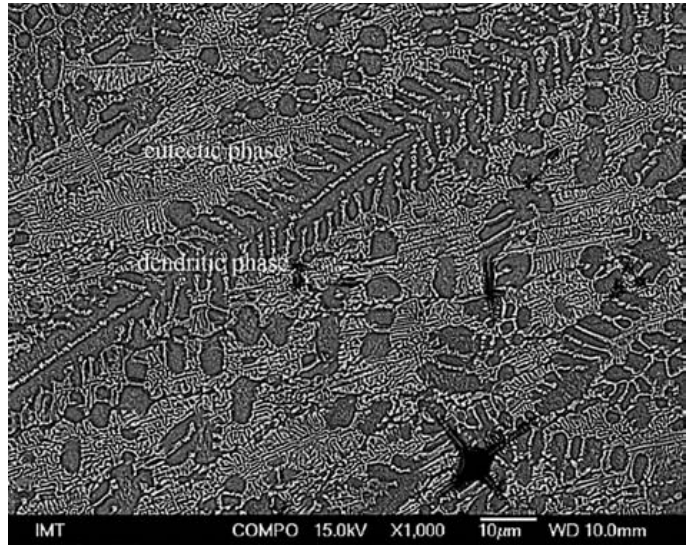

Figure 5: Backscattered-electron image of NiTi strand at $1000 \times$ magnification

Slika 5: Posnetek povratno-sipanih elektronov NiTi palice pri 1000× povečavi

lamellar eutectic structure $\left(\mathrm{NiTi}+\mathrm{TiNi}_{3-\mathrm{x}}\right)$ from the residue of the melt. EDS analysis at $5 \mathrm{keV}$ showed that both the dendritic phase and the dark lamellas of eutectic, have a composition of approximately $50 \%$ of amount fractions of $\mathrm{Ni}$ and $50 \%$ of amount fractions of
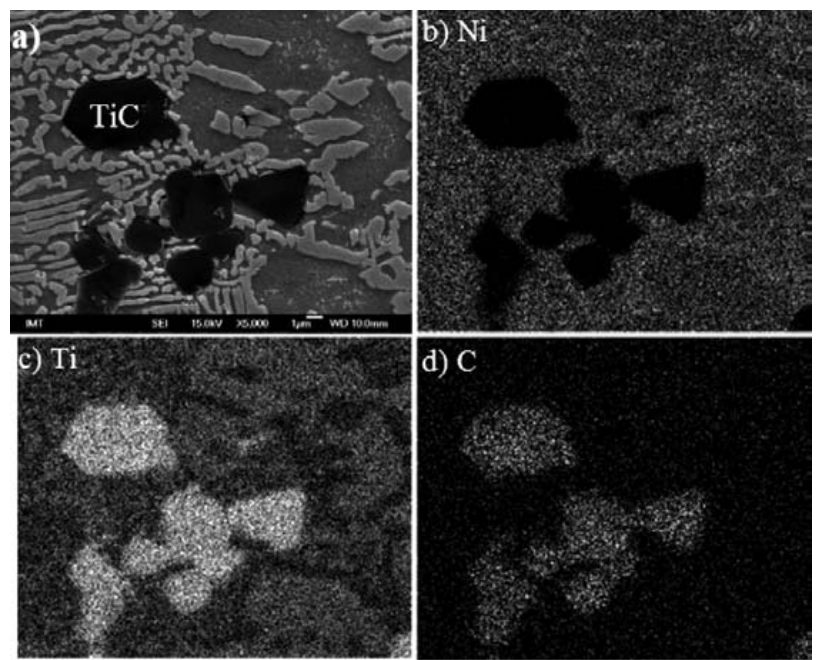

e) Fe

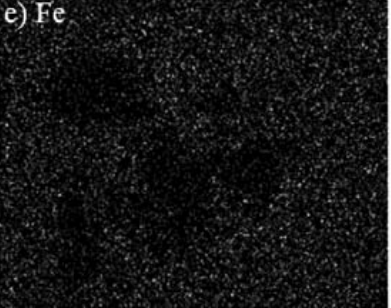

Figure 6: a) SE image of NiTi strand at 5000× magnification of area where the TiC inclusions are present, b), c), d) and e) elemental mapping at the microstructural level by scanning electron microscopy (SEM) with energy dispersive X-ray spectrometry (EDS) in the area with $\mathrm{TiC}$ inclusions

Slika 6: a) SE-posnetek NiTi palice pri 5000× povečavi v območju, kjer so prisotni TiC vključki, b), c), d) in e) elementna analiza na mikrostrukturni ravni z vrstičnim elektronskim mikroskopom (SEM) z energijo disperzijsko rentgensko spektrometrijo (EDS) v območju $\mathrm{s}$ TiC vključki 
Ti, while bright lamellas of eutectic have a composition of $33 \%$ of amount fractions of $\mathrm{Ti}$ and $67 \%$ of amount fractions of $\mathrm{Ni}$.

The secondary electron (SE) image (Figure 6) reveals in addition to the dendritic structure also the presence of the individual inclusions. The EDS analysis showed that the inclusions are titanium carbide (TiC). Carbon originates from the clay-graphite crucible and diffuses into the melt during the melting and reacts there with the Ti. The Gibbs free energy for the formation of $\mathrm{TiC}$ is very low, so the conditions for the formation of TiC are very favourable. From the results of the EDS analysis it appears that the carbon is located only in the form of carbides, and there is none in the other phases. $\mathrm{Ni}$ and $\mathrm{Fe}$ are located in the dendrites and the matrix, but not in the carbides, while titanium is present in all the phases. Another important fact is that, during CVC, there was no contamination with oxygen because no dissolved oxygen or oxides were observed in the strand. In this manner it could be concluded that the vacuum was appropriate.

So far several VIM + CVC experiments for the production of NiTi strand were made. In the first attempt the chemical composition of the strand was constant, but incorrect. During further attempts it varied during drawing in the direction of reducing the nickel content. It was concluded that the mixing of the melt was inappropriate. Insufficient stirring was attributed to the $4-\mathrm{kHz}$ inductor. To achieve better stirring, a low-frequency generator should be modulated. Costs for something like that are too high and therefore the remelting method will be further used. CVC will be held with an in advance prepared NiTi alloy. Instead of Fe starter bar, that probably introduced Fe impurities in the alloy, a starter bar with a Ti-tip will be applied. The vacuum by VIM was appropriate, because no oxygen or oxides were found in the strand, but the crucible will also need to be modified due to some concentration of $\mathrm{TiC}$ phase in the strand.
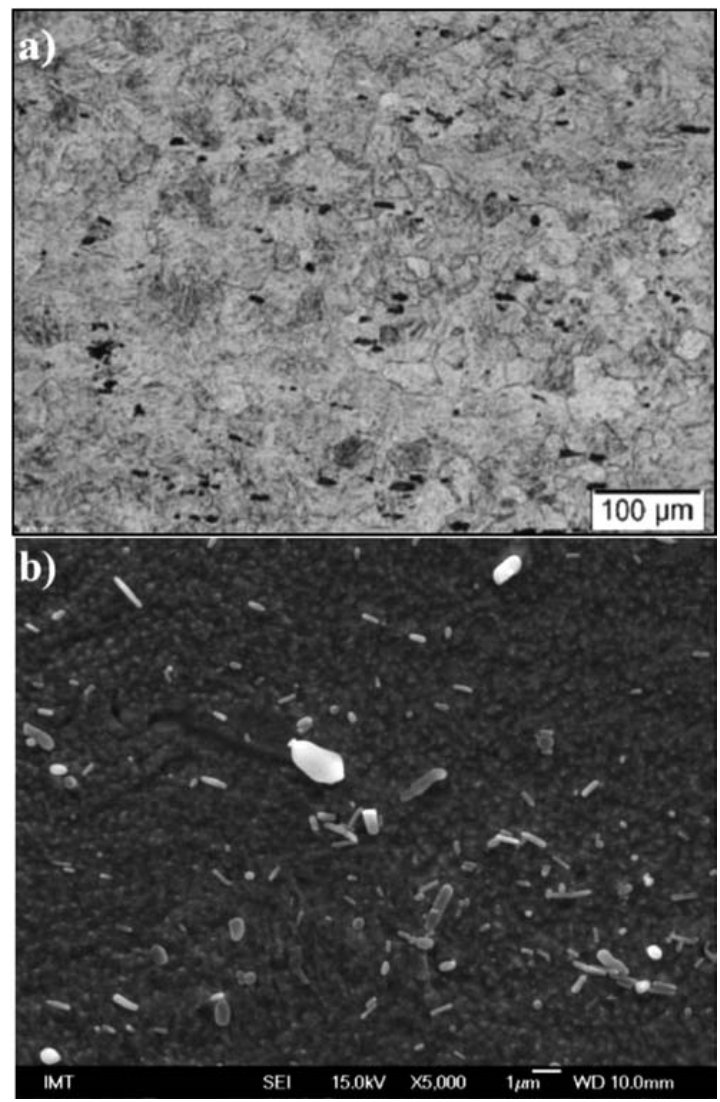

Figure 7: a) Light microscope image of commercially available NiTi alloy at $100 \times$ magnification and b) SE image of commercially available NiTi alloy at 5000× magnification

Slika 7: a) Posnetek komercialno dostopne NiTi zlitine na svetlobnem mikroskopu pri $100 \times$ povečavi in b) SE slika komercialno dostopne NiTi zlitine pri $5000 \times$ povečavi

\subsubsection{Commercially available NiTi alloy}

The light microscope image (Figure 7a) reveals relatively large grains $(>20 \mu \mathrm{m})$; the grain boundaries are clearly noticeable and the grains have different shapes and sizes.

The secondary-electron image made with SEM (Figure $7 \mathbf{b}$ ) reveals that the commercially available NiTi
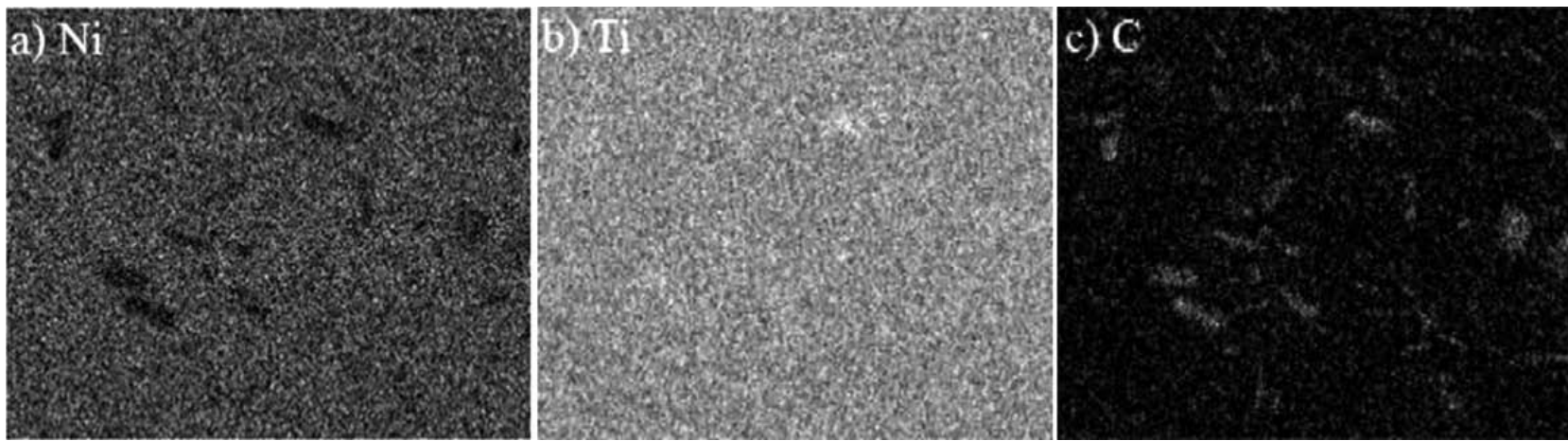

Figure 8: a), b) and c) Elemental mapping at the microstructural level by scanning electron microscopy (SEM) with energy-dispersive X-ray spectrometry (EDS) of commercial NiTi alloy

Slika 8: a), b) in c) Elementna analiza komercialne NiTi zlitine na mikrostrukturni ravni z vrstičnim elektronskim mikroskopom (SEM) z energijsko disperzijsko rentgensko spektrometrijo (EDS) 


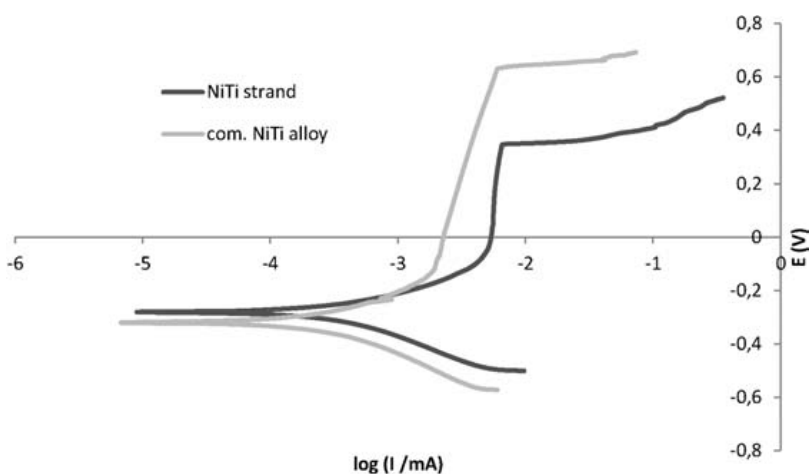

Figure 9: Potentiodynamic curves for NiTi strand and commercially available NiTi alloy

Slika 9: Potenciodinamske krivulje NiTi palice in komercialno dostopne NiTi zlitine

Table 1: Electrochemical parameters determined from the potentiodynamic curves measured for the NiTi strand and the commercially available NiTi alloy

Tabela 1: Elektrokemijski parametri, določeni iz potenciodinamskih krivulj, izmerjenih za NiTi palico in komercialno dostopno NiTi zlitino

\begin{tabular}{|c|c|c|c|c|c|}
\hline & $\begin{array}{c}E_{\text {corr }} \\
(\mathrm{mV})\end{array}$ & $\begin{array}{c}I_{\text {corr }} \\
(\mu \mathrm{A})\end{array}$ & $\begin{array}{c}E_{\text {bd }} \\
(\mathrm{mV})\end{array}$ & $\begin{array}{c}I_{\mathrm{bd}} \\
(\mu \mathrm{A})\end{array}$ & $\begin{array}{c}v_{\text {corr }} \\
(\mathrm{mmpy})\end{array}$ \\
\hline NiTi strand & -287.1 & 0.343 & 348.5 & 6.767 & $3.201 \cdot 10^{-3}$ \\
\hline com. NiTi alloy & -324.9 & 0.328 & 625.8 & 5.948 & $2.828 \cdot 10^{-3}$ \\
\hline
\end{tabular}

$E_{\text {corr }}$ - corrosion potential determined from potentiodynamic curves; $I_{\text {corr }}-$ corrosion current; $E_{\text {bd }}-$ breakdown potential; $I_{\text {bd }}-$ breakdown current; and $v_{\text {corr }}-$ corrosion rate

alloy consist of two phases. EDS analysis showed that the prevailing phase is $\mathrm{NiTi}$, containing $50 \%$ of amount fractions of $\mathrm{Ni}$ and $50 \%$ of amount fractions of Ti. The second phase is carbon rich phase $(33.3 \%$ of amount fractions of $\mathrm{C}, 40.12 \%$ of amount fractions of $\mathrm{Ti}$, $26.59 \%$ of amount fractions of $\mathrm{Ni}$ ). Figure 8 shows the distribution of elements in the individual phases.

\subsection{Potentiodynamic test}

Figure 9 shows the potentiodynamic curves for NiTi strand and commercially available NiTi alloy, while Table 1 contains the quantitative results of the measurements. Corrosion potential and current, and breakdown potential and current values were obtained by graphic extrapolation.

The corrosion potential of the NiTi strand is $38 \mathrm{mV}$ higher than for the commercially available NiTi alloy, which means that the passive layers spontaneously developed on the NiTi strand are less affected by environmental factors. The presence of a wider passivation range was observed for the commercially available NiTi alloy, while for the NiTi strand the passivity occurs in a narrower range of potentials, indicating a higher tendency for localized corrosion. On the surface of the nitinol a double layer is formed. The outer layer is $\mathrm{TiO}_{2}$ and the inner layer is $\mathrm{TiNi}_{3}$. When the thickness of the $\mathrm{TiO}_{2}$ layer increases, two phenomena play a competing role. First, since Ni atoms are diffusing further away from the surface, they accumulate in the region with the lowest oxidation state (close to the oxide-metal interface). Second, as $\mathrm{TiNi}_{3}$ appears as a line phase in the $\mathrm{Ni}-\mathrm{Ti}$ phase diagram, the amount of $\mathrm{Ni}$ in the intermetallic $\mathrm{TiNi}_{3}$ layer becomes saturated upon formation of this layer. As a result it will be more energetically favourable to form metallic particles within the $\mathrm{TiO}_{2}$ layer than increase the thickness of the intermetallic layer. ${ }^{20}$ Breakdown of the passive film occurs as a result of thickening of the oxide layer, leading to an increase in the size of the nickel particles in the outer oxide layer. These particles cause local stress, so the layer cracks, which facilitates the progress of corrosion. The commercially available NiTi alloy has higher breakdown potential, meaning it will form thicker oxide layer before the collapse. The corrosion rate of the commercially available NiTi alloy is lower, so it is more corrosion resistant.

\subsection{Impedance test}

Electrochemical impedance spectroscopy (EIS) measurements were performed at open circuit potential conditions in a simulated physiological fluid for 8 days. Figure 10 shows the Nyquist impedance diagrams for the NiTi strand and the commercially available NiTi alloy. The analysed spectra proposed an equivalent circuit, considering an outer titanium oxide layer with

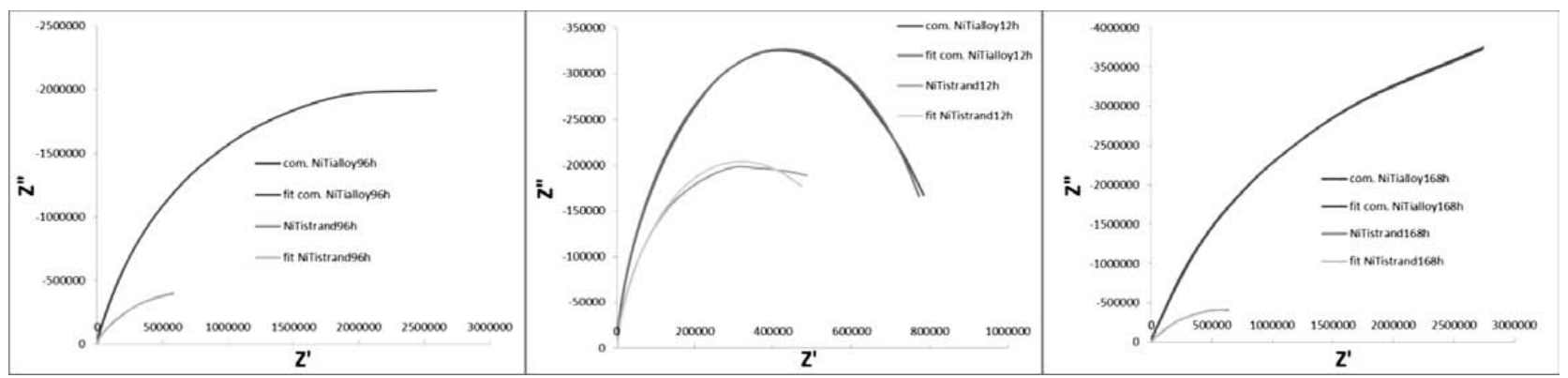

Figure 10: Nyquist diagrams for the NiTi strand and the commercially available NiTi alloy with corresponding fit after a) $12 \mathrm{~h}$, b) $96 \mathrm{~h}$, and c) $168 \mathrm{~h}$ of immersion

Slika 10: Nyquistovi diagrami NiTi palice in komercialno dostopne NiTi zlitine, z ustreznimi prilegajočimi krivuljami po času izpostavljenosti: a) $12 \mathrm{~h}, \mathrm{~b}) 96 \mathrm{ur}$, in c) $168 \mathrm{~h}$ 


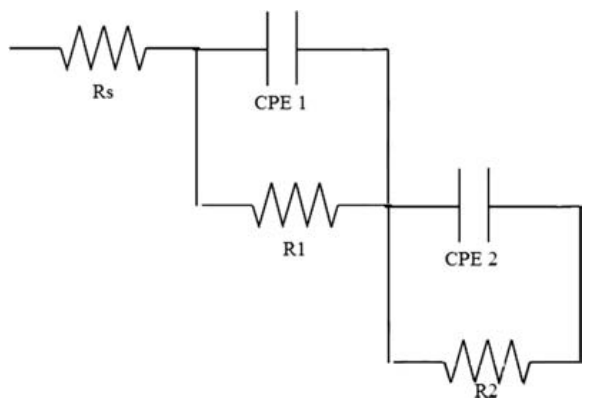

Figure 11: Equivalent circuit of two-layer model used for the interpretation of the measured impedance spectra of NiTi alloy Slika 11: Ekvivalentno vezje uporabljeno za razlago izmerjenih impedančnih spektrov NiTi zlitine na osnovi dvoslojnega modela

corrosion resistance $R_{1}$ and an inner $\mathrm{TiNi}_{3}$ layer with resistance $R_{2}$ (Figure 11), where $R_{\mathrm{S}}$ is the resistance of the solution. The use of a constant phase element (CPE) was required to account for the non-ideal capacitive response observed as a depressed semicircle when the spectra were plotted in the corresponding Nyquist diagrams. The $\mathrm{CPE}$ originates from the surface roughness and inhomogeneities present in the titanium oxide layers at the microscopic level. ${ }^{21}$

Table 2: Corrosion resistance of NiTi strand and commercially available NiTi alloy in outer $\left(R_{1}\right)$ and inner $\left(R_{2}\right)$ oxide layer, and total corrosion resistance $R_{\mathrm{p}}$ at certain time of immersion

Tabela 2: Korozijska odpornost NiTi palice in komercialno dostopne NiTi zlitine $\mathrm{v}$ zunanji $\left(R_{1}\right)$ in notranji $\left(R_{2}\right)$ plasti oksida ter skupna odpornost proti koroziji $R_{\mathrm{p}}$ pri določenem času izpostavljenosti

\begin{tabular}{|c|c|c|c|c|c|c|}
\hline$t / \mathrm{h}$ & $\begin{array}{c}R_{\text {1com }} \\
/ \Omega\end{array}$ & $\begin{array}{c}R_{2 \text { com }} \\
/ \Omega\end{array}$ & $\begin{array}{c}R_{1 \text { strand }} \\
/ \Omega\end{array}$ & $\begin{array}{c}R_{2 \text { strand }} / \boldsymbol{\Omega} \\
/ \boldsymbol{R}\end{array}$ & $\begin{array}{c}R_{\mathrm{p} \text { com }} / \boldsymbol{\Omega} \\
R_{\mathrm{p}, \text { strand }} / \boldsymbol{\Omega}\end{array}$ \\
\hline 1 & 180400 & 328850 & 10110 & 457060 & 509250 & 467170 \\
\hline 2 & 170510 & 640510 & 10812 & 638590 & 811020 & 649402 \\
\hline 12 & 265080 & 603270 & 11854 & 736850 & 868350 & 748704 \\
\hline 24 & 333940 & 695490 & 12652 & 764400 & 1029430 & 777052 \\
\hline 48 & 387740 & 1048800 & 12903 & 939500 & 1436540 & 952403 \\
\hline 72 & 544540 & 1919700 & 28966 & 1206800 & 2464240 & 1235766 \\
\hline 96 & 702330 & 3989100 & 9377 & 1470000 & 4691430 & 1479377 \\
\hline 120 & 798180 & 5642300 & 5493 & 1500600 & 6440480 & 1506093 \\
\hline 144 & 843170 & 6984000 & 25020 & 1511900 & 7827170 & 1536920 \\
\hline 168 & 917140 & 8901100 & 96538 & 1526000 & 9818240 & 1622538 \\
\hline 192 & 1018900 & 8101300 & 35321 & 1447100 & 9120200 & 1482421 \\
\hline
\end{tabular}

As shown in Table 2, the resistances of the outer and inner oxide layers in the commercial NiTi alloy are very similar and very high, while the difference in resistance between the outer and the inner layer by the NiTi strand is very high. This means that the outer layer of the NiTi strand has Ni particles, which are the weakest link in the corrosion resistance of the NiTi alloy. Resistance values in the outer layer of NiTi strand are so low $(<10000 \Omega)$, that they present no obstacle in the progress of corrosion that can occur hazardous nickel ions outleaching from this layer into the surrounding area. Corrosion has slower progress in the inner $\mathrm{TiNi}_{3}$ layer.

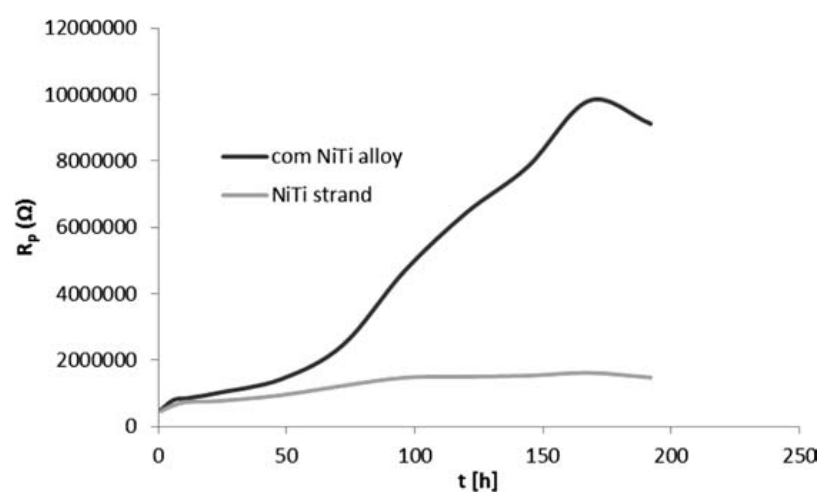

Figure 12: $R_{\mathrm{p}}$ vs time diagram for NiTi strand and commercially available NiTi alloy

Slika 12: Diagram $R_{\mathrm{p}}$ proti času NiTi palice in komercialno dostopne NiTi zlitine

Figure 12 represents the polarization or a totally corrosion resistance $R_{\mathrm{p}}$ as a function of time. $R_{\mathrm{p}}$ can be calculated according to Equation (1):

$$
R_{\mathrm{p}}=R_{1}+R_{2}
$$

as a function of time. The slope of the commercial NiTi alloy increases rapidly with time, while the slope of NiTi strand increases slightly with time. It is clear that the corrosion resistance of the commercial NiTi alloy is much greater than that of the NiTi strand at any time. The main reasons for the poorer corrosion resistance of the NiTi strand are a lower homogeneity and a lower titanium content.

\section{CONCLUSIONS}

From this study the following conclusions can be drawn:

- a dendritic microstructure of the NiTi strand was formed while VIM+CVC,

- the chemical composition of the NiTi strand varied through the cross and longitudinal sections, so the drawing process by CVC is not optimal,

- TiC and Fe phases were identified in the NiTi strand,

- the commercially available NiTi alloy has a higher breakdown potential than the NiTi strand, meaning it will have thicker, more stable oxide layer before the collapse,

- the corrosion resistance of the commercial NiTi alloy is much greater than that of NiTi strand at any time,

- $10 \%$ deficit of titanium in NiTi strand is reflected in poorer corrosion resistance properties,

- despite the fact that the corrosion resistance of the NiTi strand is not sufficient, we have successfully cast NiTi strand by VIM + CVC processes, so it is evident that it is possible to produce such an alloy in this way. 


\section{A. STAMBOLIĆ et al.: CONTINUOUS VERTICAL CASTING OF A NiTi ALLOY}

\section{REFERENCES}

${ }^{1}$ A. Tuissi, P. Bassani, A. Mangioni , L. Toia, F. Butera, Fabrication process and characterization of NiTi wires for actuators, SMST2004: Proceedings of the International Conference on Shape Memory and Superelastic Technologies, Baden-Baden, 2004, 501-508

${ }^{2}$ P. R. Halani, I. Kaya, Y. C. Shin, H. E. Karaca, Phase transformation characteristics and mechanical characterization of nitinol synthesized by laser direct deposition, Materials Science \& Engineering A, 559 (2013), 836-843, doi:10.1016/j.msea.2012.09.031

${ }^{3}$ J. Frenzel, Z. Zhang, K. Neuking, G. Eggeler, High quality vacuum induction melting of small quantities of NiTi shape memory alloys in graphite crucibles, Journal of Alloys and Compounds, 385 (2004) 1-2, 214-223, doi:10.1016/j.jallcom.2004.05.002

${ }^{4}$ I. Milošev, B. Kapun, The corrosion resistance of Nitinol alloy in simulated physiological solutions Part 1: The effect of surface preparation, Materials Science and Engineering C, 32 (2012) 5, 1087-1096, doi:10.1016/j.msec.2011.11.007

${ }^{5}$ C. H. Fu, M. P. Sealy, Y.B. Guo, X.T. Wei, Finite element simulation and experimental validation of pulsed laser cutting of nitinol, Journal of Manufacturing Processes, 19 (2015), 81-86, doi:10.1016/j.jmapro. 2015.06.005

${ }^{6}$ B. Lin, K. Gall, H. J. Maier, R. Waldron, Structure and thermomechanical behavior of NiTiPt shape memory alloy wires, Acta Biomaterialia, 5 (2009) 1, 257-267, doi: 10.1016/j.actbio.2008.07.015

${ }^{7}$ J. M. McNaney, V. Imbeni, Y. Jung, P. Papadopoulos, R. O. Ritchie, An experimental study of the superelastic effect in a shape-memory Nitinol alloy under biaxial loading, Mechanics of Materials, 35 (2003), 969-986, doi:10.1016/S0167-6636(02)00310-1

${ }^{8}$ A. Saigal, M. Fonte, Solid, shape recovered "bulk" Nitinol: Part I Tension - compression asymmetry, Materials Science and Engineering A, 528 (2011) 16-17, 5536-5550, doi:10.1016/j.msea.2011.03. 060

${ }^{9}$ K. Otsuka, X. Ren, Physical metallurgy of Ti-Ni based shape memory alloys. Progress in Materials science, 50 (2005) 5, 511-678, doi:10.1016/j.pmatsci.2004.10.001

${ }^{10}$ F. M. Ashby, R. H. D. Jones, Engineering Materials 2: An Introduction to Microstructures, Processing and Design, Second Edition, Butterworth-Heinemann, 1998
${ }^{11}$ J. Beddoes, M. J. Bibby, Principles of Metal Manufacturing Processes, Second Edition, Butterworth-Heinemann, 2003

${ }^{12}$ H. Fredriksson, U. Åkerlind, Materials Processing during Casting, First Edition, Wiley, 2006

${ }^{13}$ M. Ferry, Direct Strip Casting of Metals and Alloys, First Edition, Woodhead Publishing Limited and CRC Press LLC, 2006

${ }^{14}$ M. J. Mahtabi, N. Shamsaei, M. R. Mitchell, Fatigue of Nitinol: The state-of-the-art and ongoing challenges, Journal of the mechanical behavior of biomedical materials, 50 (2015), 228-254, doi:10.1016/ j.jmbbm.2015.06.010

${ }^{15} \mathrm{~J}$. Ferčec, R. Rudolf, Theoretical calculation of stress for the start of stress induced martensitic phase transformation in the Shape Memory Alloys NiTi, Anali Pazu, 3 (2013) 2, 75-78

${ }^{16}$ T. Hu, C. Chu, L. Yin, Y. Pu, Y. Dong, C. Guo, X. Sheng, J.-CY Chung, P.-K. Chu, In vitro biocompatibility of titanium-nickel alloy with titanium oxide film by $\mathrm{H}_{2} \mathrm{O}_{2}$ oxidation, Trans. Nonferrous Met. Soc. China, 17 (2007), 553-557

${ }^{17}$ D. Vojtěch, M. Voděrová, J. Fojt, P. Novák, T. Kubásek, Surface structure and corrosion resistance of short-time heat-treated NiTi shape memory alloy, Applied Surface Science, 257 (2010) 5, 1573-1582, doi:10.1016/j.apsusc.2010.08.097

${ }^{18}$ S. A. Shabalovskaya, H. Tian, J. W. Anderegg, D. U. Schryvers, W. U. Carroll, J. Van Humbeeck, The influence of surface oxides on the distribution and release of nickel from Nitinol wires, Biomaterials, 30 (2009) 4, 468-477, doi:10.1016/j.biomaterials.2008.10.014

${ }^{19}$ S. A. Shabalovskaya, G. C. Rondelli, A. L. Undisz, J. W. Anderegg, T. D. Burleigh, M. E. Rettenmayr, The electrochemical characteristics of native Nitinol surfaces, Biomaterials, 30 (2009) 22, 3662-3672, doi:10.1016/j.biomaterials.2009.03.034

${ }^{20}$ H. Tian, D. Schryvers, D. Liu, Q. Jiang, J. Van Humbeeck, Stability of $\mathrm{Ni}$ in nitinol oxide surfaces, Acta Biomaterialia, 7 (2011) 2, 892-899, doi:10.1016/j.actbio.2010.09.009

${ }^{21}$ J. Izquierdo, M. B. González-Marrero, M. Bozorg, B. M. Fernández-Pérez, H. C. Vasconcelos, J. J. Santana, R. M. Souto, Multiscale electrochemical analysis of the corrosion of titanium and nitinol for implant applications, Electrochimica Acta, 203 (2016), 366-378, doi:10.1016/j.electacta.2016.01.146 